\title{
ANALISIS GAYA HIDUP HEDONIS, HARGA, DAN KUALITAS PRODUK SERTA PENGARUHNYA TERHADAP KEPUTUSAN PEMBELIAN SEPEDA DI ERA PANDEMI COVID-19
}

\author{
Aji Rama Prasetiyo \\ Universitas Negeri Surabaya \\ Aji.17080574069@mhs.unesa.ac.id \\ Anik Lestari Andjarwati \\ Universitas Negeri Surabaya \\ Aniklestari@unesa.ac.id
}

\begin{abstract}
The Pandemic Covid-19 makes many people have to live their lives by starting new habits. The form of activity to maintain the health of the body is to exercise. Cycling is one of the trending sports that people love during the Covid-19 pandemic. It was noted that there was a demand for the domestic bicycle market. Bicycle manufacturers are experiencing intense competition. They compete to provide bicycles of good quality at competitive prices. The existence of this tren raises the community's hedonic lifestyle, such as shopping activities and hunting bicycles for fun. The purpose of this research to analyze the effect of hedonic lifestyle, price, and product quality on United's bicycle purchase decisions in Tulungagung Regency. This study uses a sample of 220 respondents who live in Tulungagung Regency with male and female genders of at least 16 years. The sampling method was judgmental sampling with a Likert scale as a measuring instrument. The analysis in this research uses multiple linear regression equation models with SPSS 26. The results showed that the variables of hedonic lifestyle, price, and product quality significantly and positively influenced purchase decisions. As a suggestion, United can increase sales by offering affordable prices and still provide the best quality.
\end{abstract}

Keywords: hedonic lifestyle; price; product quality; purchasing decisions.

\section{PENDAHULUAN}

Perkembangan zaman dan kemajuan teknologi semakin memengaruhi kehidupan masyarakat suatu negara dari gaya hidup, pola pikir, sikap serta perilaku. Semakin canggih teknologi informasi membuat persaingan dalam dunia bisnis menjadi ketat. Pelaku bisnis dituntut untuk memberikan inovasi agar selalu dapat bertahan dan bersaing dengan kompetitor yang lainnya. Dengan berkembangnya inovasi, banyak sekali industri yang membuat produk-produk baru. Industri yang mengalami perkembangan pesat adalah industri manufaktur. Berkembangnya industri manufaktur di Indonesia dibuktikan dengan menyumbangkan alokasi sebanyak 20 persen untuk Produk Domestik Bruto (PDB) dan menjadikan Indonesia menempati posisi kelima diantara negara G20 (Nurhanisah, 2019).

Pada 2020 sektor industri mengalami penurunan akibat dampak pandemi Covid-19. Efeknya telah membuat kemunduran bagi sektor industri dan hanya sekitar 40 persen dari total keseluruhan yang masih dapat bertahan dengan adanya permintaan produksi (Handayani, 2020). Salah satu industri yang mampu bertahan adalah industri sepeda. Munculnya kembali tren gowes di tengah pandemi Covid-19 membuat jumlah permintaan terhadap sepeda ikut meningkat. Tren bersepeda di Indonesia berawal pada Maret 2020 hingga Juni yang menjadi puncaknya. Kegiatan tersebut digemari oleh masyarakat dari berbagai kalangan usia mulai remaja, dewasa, sampai dengan lansia. Adapun kategori untuk umur remaja antaranya 11-19 tahun, dewasa berkisar 20-60 tahun, dan yang berusia lebih dari 60 tahun digolongkan sebagai lansia (Kristian, 2020). Terdapat tiga faktor utama dalam memengaruhi perilaku konsumen untuk menentukan keputusan pembelian, antara lain perbedaan individu, strategi pemasaran, dan faktor eksternal (Sumarwan, 2014:10). Menurut Sumarwan (2014:10), terdapat banyak strategi pemasaran yang dapat diambil oleh pemasar dalam bersaing memerebutkan konsumen salah satunya yang paling umum yaitu bauran pemasaran (marketing mix). Faktor perbedaan individu, 
Aji Rama Prasetiyo \& Anik Lestari Andjarwati. Analisis Gaya Hidup Hedonis, Harga, dan Kualitas Produk serta Pengaruhnya terhadap Keputusan Pembelian Sepeda di Era Pandemi Covid-19

meliputi motivasi, kepribadian, gaya hidup, sikap dan agama. Sedangkan faktor eksternal yang berasal dari lingkungan individu seperti anggota keluarga, kelompok acuan, kebudayaan, dan teknologi informasi. Seiring dengan perkembangan teknologi dan kemajuan zaman membuat perubahan terhadap gaya hidup manusia. Terdapat bermacam-macam gaya hidup yang dianut seseorang, antara lain gaya hidup konsumtif, mandiri, dan hedonis (Chaney, 2004:15). Indonesia saat ini lebih besar menganut gaya hidup hedonis yang telah melekat pada masyarakat yang tinggal di daerah kota-kota besar. Penelitian yang dilakukan Rinandiyana et al. (2018) mendukung pernyataan di atas bahwa mayoritas masyarakat yang ada di Indonesia menganut gaya hidup hedonis. Mereka yang memiliki gaya hidup hedonis menghabiskan waktunya dengan tujuan mendapatkan kebahagiaan dan kepuasan terhadap hal yang bersifat duniawi. Rinandiyana et al. (2018) menyebutkan bahwa terdapat tiga aspek gaya hidup hedonis, meliputi aktivitas (activity), ketertarikan (interest), dan pendapat (opinion). Individu yang menganut gaya hidup hedonis memiliki ciri-ciri sifat, seperti impulsif, irrasional, pengikut, dan mudah dipersuasif (Kasali, 2003:242). Indrawati (2015) menunjukkan adanya pengaruh yang signifikan dan positif gaya hidup hedonis terhadap keputusan pembelian. Diperkuat oleh penelitian Rizaldi (2016), terdapat hubungan signifikan gaya hidup hedonis terhadap keputusan pembelian.

Pada umumnya untuk menentukan keputusan pembelian konsumen harus melalui beberapa tahapan, seperti mengenali masalah, proses mencari informasi, mengevaluasi pilihan alternatif, proses pembelian dan tindakan setelah pembelian (Kotler dan Keller, 2012:235). Dengan banyaknya pilihan produk yang tersedia konsumen harus mampu menentukan pilihan alternatif. Terdapat tiga atribut penting yang sering digunakan konsumen untuk mengevaluasi pilihan alternatif, yakni harga, merek, dan produsen (Engel et al., 1995:368). Konsumen akan cenderung melakukan perbandingan harga produk sebagai bahan evaluasi yang disesuaikan dengan manfaat, nilai, serta kegunaan. Kotler dan Keller (2012:63) menyatakan terdapat beberapa dimensi harga, seperti harga sesuai dengan kualitas, harga terjangkau, harga bersaing, harga sesuai dengan manfaat, dan diskon. Semakin tinggi harga produk yang ditetapkan maka keputusan konsumen untuk melakukan pembelian akan rendah dan sebaliknya jika harga yang ditetapkan rendah, maka keputusan pembelian akan tinggi. Dengan penetapan harga yang sesuai daya beli, maka konsumen akan memilih produk ataupun jasa tersebut. Andrianto \& Idris (2013) mendukung pernyataan di atas, harga berpengaruh secara signifikan terhadap keputusan pembelian. Lebih lanjut Hustić \& Gregurec (2015) dan Firdausy \& Idawati (2017) menunjukkan adanya pengaruh yang signifikan dan positif antara harga terhadap keputusan pembelian. Namun, hasil ini tidak sejalan dengan Pardede \& Haryadi (2017) bahwa harga tidak berpengaruh terhadap keputusan pembelian.

Minat konsumen dalam membeli melihat dari seberapa bagus kualitas produk yang ditawarkan (Brata et al., 2017). Menurut Tjiptono (2008:25-26), kualitas produk yang bagus dapat diukur dari beberapa atribut, seperti kinerja (performance), estetika (aesthetics), keistimewaan tambahan (feature), daya tahan (durability), kemudahan pelayanan (service ability), ketangguhan (reliability), kesetaraan dengan spesifikasi (conformance to specification), dan persepsi kualitas (perceived quality). Kualitas produk dapat memberikan dorongan terhadap semua elemen pada strategi pemasaran yang berguna untuk menciptakan keputusan pembelian konsumen (Aaker, 1991:127). Alfred (2013), Ago et al. (2015), dan Rahman \& Sitio (2019) menunjukkan adanya pengaruh secara signifikan harga terhadap keputusan pembelian. Tetapi, terdapat perbedaan hasil dengan Pardede \& Haryadi (2017) dan Pandensolang \& Tawas (2015) bahwa kualitas produk tidak memengaruhi keputusan pembelian.

Salah satu brand sepeda nasional yang sudah terkenal sejak dahulu adalah United. United merupakan brand sepeda yang diproduksi oleh PT. Terang Dunia Internusa yang sudah berdiri sejak tahun 1991. Terdapat banyak jenis sepeda yang diproduksi seperti sepeda balap (road), mountain, trail, urban, dan cross country. Selain membuat sepeda, PT. Terang Dunia Internusa juga memproduksi sparepart untuk pasar dalam negeri maupun diekspor ke luar negeri (Unitedbike.com, 2020). United menjadi salah satu brand sepeda sukses di Indonesia dengan masuk Top Brand Award secara berturut-turut dan menempati posisi ketiga untuk kategori sepeda dewasa dari tahun 2015 hingga 2017 (Top Brand Award, 2020). Tetapi, tahun 2020 ketika permintaan pasar sepeda meningkat yang disebabkan oleh naiknya tren bersepeda, United justru mengalami penurunan posisi pada Top Brand Index kategori 
sepeda dewasa. Posisi United tergantikan oleh merek-merek baru. Hal tersebut membuktikan persaingan yang ketat dari setiap produsen untuk memberikan produk dengan harga bersaing dan kualitas yang baik.

Tulungagung adalah salah satu kabupaten yang berada di Provinsi Jawa Timur. Terletak di bagian barat daya dari kota Surabaya membuat Tulungagung menjadi salah satu kabupaten dengan destinasi wisata alam yang bervariasi salah satunya pantai (Yamin, 2017). Munculnya kembali tren bersepeda di tengah pandemi Covid-19 membuat sebagian orang melakukan aktivitasnya di luar rumah dengan bersepeda mengunjungi tempat-tempat wisata tertentu untuk mendapatkan kesenangan bersama teman ataupun keluarga (Yohanes, 2020). Penelitian ini bertujuan untuk menguji antara pengaruh gaya hidup hedonis, harga, dan kualitas produk terhadap keputusan pembelian sepeda.

\section{KAJIAN PUSTAKA DAN PENGEMBANGAN HIPOTESIS}

\section{Keputusan Pembelian}

Schiffman \& Kanuk (2010:112) menjelaskan keputusan pembelian selaku wujud keputusan dari kegiatan yang diseleksi untuk memutuskan dua opsi alternatif ataupun lebih. Lebih lanjut Kotler \& Armstrong (2012:181) mendefinisikan keputusan pembelian sebagai bentuk perilaku seseorang untuk membeli produk dari merek yang diprioritaskan. Sedangkan Setiadi (2010:332) mengartikan keputusan pembelian sebagai bagian dari proses konsumen dalam mengevaluasi serta menentukan salah satu pilihan dari beberapa opsi yang tersedia. Keputusan pembelian pada penelitian ini diukur menggunakan indikator yang mengacu pada penelitian Indrawati (2015) dan Pardede \& Haryadi (2017) yang disesuaikan dengan objek penelitian ini, yaitu pilihan produk: memilih dan menentukan produk sesuai dengan kebutuhan; prioritas dalam membeli: menganggap salah satu merek lebih penting dibandingkan merek lainnya; dan waktu pembelian: menentukan waktu dalam membeli.

\section{Gaya Hidup Hedonis}

Kasali (2003:242) menyatakan gaya hidup hedonis sebagai kegiatan mencari kenikmatan hidup dengan menghabiskan waktu bermain di luar rumah, senang membeli barang mahal untuk memuaskan hasrat, dan cenderung followers. Sedangkan Utami (2012) menyatakan bahwa gaya hidup hedonis sebagai bentuk kehidupan yang mengarah pada kegiatan konsumtif dalam membeli suatu produk demi mendapatkan kesenangan duniawi. Lebih lanjut gaya hidup hedonis merupakan bentuk perilaku seseorang yang menghabiskan waktunya dengan aktivitas di luar rumah, suka bermain, merasa senang berada di keramaian, senang membelanjakan uang untuk benda yang kurang berguna, dan senantiasa mau menjadi pusat atensi (Susianto, 1993:36). Gaya hidup sendiri terdapat beberapa jenis, seperti gaya hidup konsumtif, mandiri, dan hedonis (Chaney, 2004:15). Kasali (2003:242) menjelaskan karakteristik seseorang yang menganut gaya hidup hedonis adalah mereka berperilaku impulsif, mudah terbujuk secara emosional, senang mengikuti (follower) dan selalu berusaha mendapatkan kesenangan dengan kegiatan bermain di luar rumah. Dengan memiliki sifat hedonis dalam diri individu maka hal tersebut akan memengaruhi dalam melakukan keputusan untuk membeli seuatu. Dalam penelitian ini, gaya hidup hedonis diukur menggunakan indikator dari Babin et al. (1994), Indrawati (2015), dan Rizaldi (2016) yang telah disesuaikan dengan objek penelitian, meliputi cenderung follower, gaya konsumsi, tempat, dan rekreasi.

\section{Harga}

Kotler \& Armstrong (2012:290) mendefinisikan harga yakni beberapa uang yang wajib dibayarkan agar memeroleh nilai serta manfaat dari barang yang diinginkan konsumen. Lebih lanjut, menurut Tjiptono (2008:151) harga merupakan ukuran nominal yang digunakan untuk menukarkan hak kepemilikan dari barang maupun jasa. Kotler dan Keller (2012:67) menjelaskan harga merupakan nilai uang yang digunakan dalam menghasilkan pendapatan serta biaya. Indikator yang digunakan untuk mengukur variabel harga dalam penelitian ini mengacu pada Andrianto \& Idris (2013), Lien et al. (2015), dan Pardede \& Haryadi (2017) dengan objek yang telah disesuaikan, yaitu harga bersaing, 
Aji Rama Prasetiyo \& Anik Lestari Andjarwati. Analisis Gaya Hidup Hedonis, Harga, dan Kualitas Produk serta Pengaruhnya terhadap Keputusan Pembelian Sepeda di Era Pandemi Covid-19

harga terjangkau, harga sesuai manfaat, harga sesuai kualitas, dan harga memengaruhi daya beli konsumens.

\section{Kualitas Produk}

Kotler \& Armstrong (2012:283) menjelaskan bahwa kualitas produk ialah kesanggupan dari suatu produk dalam menjalankan fungsinya. Kemudian Kotler dan Keller (2012:142) mendefinisikan kualitas produk sebagai kesanggupan produk dalam menjalankan fungsinya yang terdapat beberapa atribut di dalamnya. Lebih lanjut, Tjiptono (2008:25) menyebutkan kualitas produk ialah gabungan dari sifat dan karakteristik produk dalam memenuhi kebutuhan pelanggan, serta menilai sejauh mana sifat maupun karakteristik tersebut menjalankan fungsinya. Sehingga, kualitas produk adalah seberapa jauh suatu produk dalam menjalankan fungsinya untuk memberikan manfaat bagi seorang konsumen. Kualitas produk pada penelitian ini diukur menggunakan indikator yang mengacu pada Pardede \& Haryadi (2017) dan Rahman \& Sitio (2019) yang telah disesuaikan dengan objek penelitian, antara lain kinerja (performance), daya tahan (durability), fitur (feature), dan keragaman produk.

\section{Hubungan antar Variabel}

Kasali (2003:242) menjelaskan mereka yang menganut gaya hidup hedonis akan mengatasi masalahnya dengan keluar rumah untuk bermain, belanja, ataupun berkumpul untuk mendapatkan kesenangan. Indrawati (2015) menyatakan adanya pengaruh antara gaya hidup hedonis terhadap keputusan pembelian secara signifikan serta positif. Lebih lanjut Rizaldi (2016) membuktikan gaya hidup hedonis secara signifikan dan positif memengaruhi keputusan pembelian.

H1: Terdapat pengaruh positif dan signifikan gaya hidup hedonis terhadap keputusan pembelian.

Salah satu hal yang sangat penting dalam persepsi pelanggan untuk membantu menentukan keputusan pembelian terhadap strategi pemasaran adalah harga (Assael, 1998:235). Hal tersebut mendukung penelitian Andrianto \& Idris (2013) harga berdampak pada keputusan pembelian secara signifikan. Hustić \& Gregurec (2015) dan Firdausy \& Idawati (2017) menyatakan harga secara positif dan signifikan memengaruhi keputusan pembelian. Namun terdapat perbedaan hasil penelitian yang dilakukan Pardede \& Haryadi (2017) tidak ada pengaruh harga terhadap keputusan pembelian.

H2: Terdapat pengaruh positif dan signifikan harga terhadap keputusan pembelian.

Aaker (2008:127) menjelaskan bahwa kualitas produk mampu mengefektifkan semua elemen strategi pemasaran untuk menciptakan keputusan-keputusan pembelian. Hasil tersebut mendukung penelitian Alfred (2013), kualitas produk berpengaruh signifikan terhadap keputusan pembelian. Ago et al. (2015), Rahman \& Sitio (2020), dan Ananingsih et al. (2018) menyatakan adanya pengaruh yang signifikan dan positif kualitas produk terhadap keputusan pembelian. Akan tetapi, Pardede \& Haryadi (2017) menunjukkan bahwa kualitas produk tidak berpengaruh terhadap keputusan pembelian.

H3: Terdapat pengaruh signifikan dan positif kualitas produk terhadap keputusan pembelian.

Kerangka penelitian dapat dilihat pada Gambar 1.

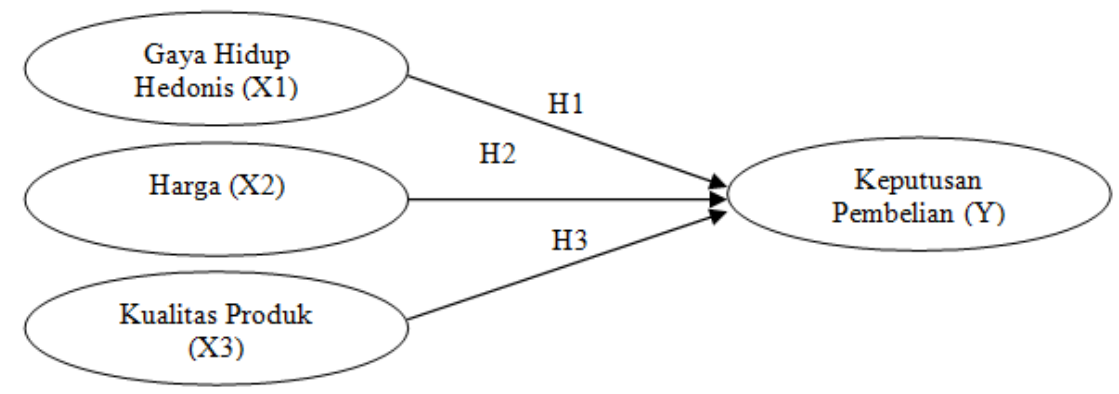

Gambar 1. KERANGKA PENELITIAN 


\section{METODE PENELITAN}

Rancangan konklusif digunakan dalam penelitian ini dengan tujuan menguji hipotesis spesifik serta hubungan dari data yang dihasilkan menggunakan analisis kuantitatif (Malhotra, 2017:90). Penelitian ini menggunakan pendekatan kausal untuk mengetahui hubungan sebab akibat antar variabel. Lokasi penelitian di Kabupaten Tulungagung. Pengambilan sampel menggunakan teknik non probability sampling dengan metode judgemental yaitu pengguna sepeda United di Kabupaten Tulungagung yang sesuai dengan karakteristik penelitian. Data primer didapat dari hasil jawaban kuisioner sebanyak 220 responden. Sedangkan data sekunder diperoleh dari literasi buku, artikel ilmiah, artikel berita, dan studi terdahulu. Skala pengukuruan menggunakan skala likert dan pengolah data IBM SPSS 26.

\section{HASIL DAN PEMBAHASAN}

Tabel 1.

HASIL UJI VALIDITAS DAN RELIABILITAS

\begin{tabular}{|c|c|c|}
\hline Item Pernyataan & $\begin{array}{l}\text { Correlated } \\
\text { Item Total }\end{array}$ & $\begin{array}{c}\text { Cronbach's } \\
\text { Alpha }\end{array}$ \\
\hline \multicolumn{3}{|l|}{ Gaya Hidup Hedonis (X1) } \\
\hline Saya selalu mengikuti tren yang sedang terjadi & 0,627 & \multirow{8}{*}{0,887} \\
\hline Saya membeli sepeda United karena sedang tren bersepeda & 0,829 & \\
\hline Saya membeli sepeda United untuk memuaskan diri sendiri & 0,756 & \\
\hline Membeli sepeda United merupakan hal yang menyenangkan & 0,770 & \\
\hline Saya menghabiskan waktu akhir pekan dengan bersepeda ke alun-alun kota & 0,734 & \\
\hline Kafe merupakan tempat favorit saya berkumpul dengan teman komunitas sepeda & 0,671 & \\
\hline Saya senang menghabiskan waktu dengan bersepeda menggunakan sepeda United & 0,836 & \\
\hline Bersepeda menggunakan sepeda United menigkatkan kualitas hidup saya & 0,787 & \\
\hline \multicolumn{3}{|l|}{ Harga $(X 2)$} \\
\hline Harga sepeda United dapat bersaing dengan merek sepeda lainnya & 0,749 & \multirow{7}{*}{0,869} \\
\hline Sepeda United memiliki harga yang terjangkau & 0,828 & \\
\hline Harga sepeda United lebih murah dibandingkan merek lainnya & 0,639 & \\
\hline Harga sepeda United sesuai dengan manfaat yang diberikan & 0,605 & \\
\hline Harga sepeda United sesuai dengan kualitas yang diberikan & 0,806 & \\
\hline Harga sepeda United sesuai dengan pendapatan saya & 0,824 & \\
\hline Harga sepeda United sesuai dengan kemampuan ekonomi saya & 0,824 & \\
\hline \multicolumn{3}{|l|}{ Kualitas Produk (X3) } \\
\hline Sepeda United dapat berfungsi dengan baik & 0,711 & \multirow{8}{*}{0,856} \\
\hline Semua komponen sepeda United dapat digunakan & 0,701 & \\
\hline Sepeda United memiliki usia pakai yang lama & 0,848 & \\
\hline Sepeda United lebih awet dibandingkan merek sepeda lainnya & 0,738 & \\
\hline Fitur pengereman cakram sepeda United bekerja dengan baik & 0,834 & \\
\hline Suspensi yang digunakan sepeda United meningkatkan kenyamanan & 0,784 & \\
\hline Sepeda United memiliki berbagai pilihan tipe & 0,531 & \\
\hline Sepeda United memiiki varian warna bermacam-macam & 0,511 & \\
\hline \multicolumn{3}{|l|}{ Keputusan Pembelian (Y) } \\
\hline Saya membeli sepeda United karena sesuai dengan kebutuhan & 0,797 & \multirow{6}{*}{0,862} \\
\hline Saya membeli sepeda United karena modelnya bagus & 0,823 & \\
\hline Saya lebih memilih sepeda United dibandingkan dengan merek lainnya & 0,745 & \\
\hline Saya membeli sepeda United untuk meningkatkan imunitas tubuh & 0,751 & \\
\hline Saya membeli sepeda United untuk berolah raga di akhir pekan & 0,831 & \\
\hline Saya membeli sepeda United saat tren bersepeda di tengah pandemi Covid-19 & 0,712 & \\
\hline
\end{tabular}

Sumber: Output SPSS (2021, data diolah) 
Aji Rama Prasetiyo \& Anik Lestari Andjarwati. Analisis Gaya Hidup Hedonis, Harga, dan Kualitas Produk serta Pengaruhnya terhadap Keputusan Pembelian Sepeda di Era Pandemi Covid-19

Tabel 1. hasil uji validitas didapatkan dengan menyebar kuisioner kepada 30 responden awal untuk mengetahui kevalidan dari setiap item pernyataan yang dibuat. Berdasarkan hasil uji validitas, semua item pernyataan dari setiap variabel memiliki nilai $\left(R_{\text {hitung }}\right)>R_{\text {tabel }}(0,361)$. Sehingga item pernyataan dapat digunakan untuk mengukur pengaruh variabel bebas meliputi gaya hidup hedonis, harga, dan kualitas produk terhadap keputusan pembelian sebagai variabel terikat. Dari hasil uji reliabilitas didapatkan hasil bahwa nilai Cronbach's alpha masing-masing variabel memiliki nilai > 0,70.

\section{Karakteristik Responden}

Berdasarkan dari penyebaran kuisioner didapatkan 220 responden yang sesuai dengan kriteria penelitian. Responden merupakan masyarakat yang berdomisili di wilayah Kabupaten Tulungagung yang merupakan pengguna sepeda dari merek United. Dari hasil analisis data didapatkan hasil mayoritas responden berjenis kelamin laki-laki sebanyak 115 orang (52\%). Usia dari responden yang mendominasi direntang 16 hingga 30 tahun sejumlah 128 orang (58\%). Tingkat pendidikan akhir responden kebanyakan adalah pada jenjang SMA/SMK berjumlah 118 orang (54\%). Sebanyak 58 orang $(26,4 \%)$ memiliki status paling tinggi sebagai seorang mahasiswa. Dari rata-rata pendapatan mayoritas responden memiliki penghasilan lebih dari Rp3.000.000 setiap bulannya.

\section{Hasil Uji Asumsi Klasik}

Uji normalitas adalah pengujian untuk mengetahui distribusi normal dari variabel independen maupun dependen. Uji normalitas yang digunakan adalah uji statistik non parametric Kolmogorov-Smirnov (K-S). Hasil uji normalitas didapatkan dengan nilai Asym. Sig.(2-tailed) sebesar 0,200, sehingga data yang ada pada penelitian ini berdistribusi normal. Hal tersebut karena nilai signifikansi lebih besar dari 0,05. Hasil uji multikolonieritas variabel gaya hidup hedonis memiliki nilai tolerance 0,722 dan nilai VIF (Variance Inflation Factor) sebesar 1,385. Variabel harga dengan nilai tolerance 0,850 dan VIF sebesar 1,176. Lalu kualitas produk dengan nilai tolerance sebesar 0,755 dan nilai VIF 1,324. Dari hasil tersebut, setiap variabel memiliki nilai tolerance $>0,1$ dan nilai VIF $<10$, sehingga data penelitian ini tidak mengalami multikolonieritas. Hasil uji heteroskedastisitas, semua variabel independen memiliki nilai signifikan > 0,05 yaitu variabel gaya hidup hedonis sebesar 0,184; variabel harga dengan nilai signifikansi 0,083; dan variabel kualitas produk sebesar 0,231.

\section{Uji Regresi Linier Berganda}

Nilai konstanta $(\alpha)$ sebesar 4,740 hal tersebut berarti apabila gaya hidup hedonis, harga, dan kualitas produk bernilai nol (0), maka besarnya keputusan pembelian sepeda United adalah 4,740. Nilai koefisien 0,233 artinya terdapat pengaruh positif variabel gaya hidup hedonis terhadap keputusan pembelian. Ketika masyarakat Kabupaten Tulungagung memiliki gaya hidup hedonis tinggi, maka membuat keputusan pembelian yang dibuat semakin meningkat. Variabel harga memiliki nilai koefisien 0,199 dan positif. Ketika persepsi harga sesuai dengan yang diterima masyarakat, maka akan meningkatkan keputusan pembelian terhadap sepeda United. Variabel kualitas produk nilai koefisien sebesar 0,182 dan bertanda positif, sehingga terdapat pengaruh kualitas produk terhadap keputusan pembelian. Semakin bagus dan berkualitas produk sepeda United, maka hal tersebut akan menaikkan keputusan pembelian. Dari hasil regresi diperoleh model penelitian pada persamaan (1).

$\mathrm{Y}=4,740+0,233 \mathrm{X} 1+0,199 \mathrm{X} 2+0,182 \mathrm{X} 3$

Tabel 2.

HASIL ANALISIS REGRESI LINIER BERGANDA

\begin{tabular}{|c|c|c|c|c|c|}
\hline \multirow{2}{*}{ Model } & \multicolumn{2}{|c|}{$\begin{array}{c}\text { Unstandardized } \\
\text { Coefficients }\end{array}$} & \multirow{2}{*}{$\begin{array}{c}\text { Standardized } \\
\text { Coefficients } \\
\text { Beta }\end{array}$} & \multirow[t]{2}{*}{$\mathbf{t}$} & \multirow{2}{*}{ Sig. } \\
\hline & B & Std. Error & & & \\
\hline (Constant) & 4,740 & 2,347 & & 2,020 &, 045 \\
\hline Gaya Hidup Hedonis $\left(\mathrm{X}_{1}\right)$ & ,233 &, 050 & 317 & 4,654 &, 000 \\
\hline $\operatorname{Harga}\left(X_{2}\right)$ & 199 & ,079 & ,158 & 2,521 &, 012 \\
\hline Kualitas Produk $\left(\mathrm{X}_{3}\right)$ & 182 & ,062 & ,195 & 2,923 & ,004 \\
\hline
\end{tabular}

Sumber: Output SPSS (2021, data diolah) 


\section{Hasil Analisis Koefisien Determinasi}

Berdasarkan hasil pada tabel 3, diketahui besarnya kontribusi variabel independen yang meliputi gaya hidup hedonis, harga, dan kualitas produk terhadap keputusan pembelian sebesar 26,6\% $(0,266)$. Hal tersebut membuktikan bahwa gaya hidup hedonis, harga, dan kualitas produk memiliki pengaruh terhadap keputusan pembelian sepeda United di Kabupaten Tulungagung sebesar 26,6\% $(0,266)$, sedangkan $73,4 \%$ dipengaruhi oleh faktor lainnya.

Tabel 3.

KOEFISIEN DETERMINASI

\begin{tabular}{cccc}
\hline $\mathbf{R}$ & $\boldsymbol{R}$ Square & Adjusted $\boldsymbol{R}$ Square & Std. Error of the Estimate \\
\hline, 526 &, 277 &, 266 & 1,759 \\
\hline
\end{tabular}

Sumber: Output SPSS (2021, data diolah)

\section{Uji Hipotesis}

Pada tabel 2. nilai thitung pada variabel gaya hidup hedonis sebesar 4,654 dengan nilai signifikansi 0,000. Diperoleh hipotesis H0 ditolak dan H1 diterima, sehingga gaya hidup hedonis memiliki pengaruh terhadap keputusan pembelian. Lanjut pada variabel harga nilai thitung sebesar 2,521 dan nilai signifikansi 0,012. Sehingga $\mathrm{H} 0$ ditolak dan H2 diterima. Hal ini menunjukkan harga berpengaruh terhadap keputusan pembelian. Nilai $t_{\text {hitung }}$ sebesar 2,923 dan signifikansi 0,004 pada variabel kualitas produk. Hipotesis yang didapat $\mathrm{H} 0$ ditolak dan $\mathrm{H} 3$ diterima, sehingga kualitas produk berpengaruh terhadap keputusan pembelian.

\section{Pengaruh Gaya Hidup Hedonis terhadap Keputusan Pembelian}

Dari analisis data membuktikan hasil gaya hidup hedonis memiliki pengaruh terhadap keputusan pembelian sepeda United di Kabupaten Tulungagung. Hal tersebut membuktikan ketika seorang individu senang dengan gaya hidup hura-hura dan mengikuti berbagai hal yang sedang trening untuk kesenangan pribadi secara tidak sadar mereka telah menerapkan gaya hidup hedonis, sehingga memungkinkan untuk menciptakan banyak keputusan pembelian. Dalam hal ini responden dari Kabupaten Tulungagung merasa antusias untuk mengikuti setiap tren yang sedang ada seperti tren bersepeda di tengah pandemi Covid-19. Mereka merasa senang ketika datang ke toko untuk membeli salah satu produk sepeda yang dijual seperti merek United. Beberapa dari responden tidak menghiraukan terkait masalah keuangan, mereka tetap rela mengeluarkan uang yang tidak sedikit demi untuk membeli sepeda seperti United untuk aktivitas bersepeda dan mengikuti tren. Dengan kegiatan bersepeda mereka merasa senang dan puas karena bisa kembali beraktivitas di luar rumah setelah berbulan-bulan harus terkurung karena peraturan PSBB (Pembatasan Sosial Berskala Besar). Hasil tersebut membuktikan konsep teori dari Kasali (2003:242) gaya hidup hedonis merupakan bentuk kegiatan mencari kenikmatan hidup dengan menghabiskan waktu berkegiatan di luar rumah, membeli barang, dan cenderung follower. Dengan memiliki sifat hedonis dalam diri individu maka hal tersebut akan memengaruhi dalam melakukan keputusan untuk membeli sesuatu. Hasil penelitian Indrawati (2015) menunjukkan adanya pengaruh signifikan serta positif antara gaya hidup hedonis terhadap keputusan pembelian. Memerkuat penelitian Rizaldi (2016) bahwa gaya hidup berpengaruh signifikan dan positif terhadap keputusan pembelian.

Gaya hidup hedonis pada penelitian ini diukur dengan empat indikator, meliputi cenderung follower, gaya konsumsi, tempat, dan rekreasi. Pada indikator cenderung follower dengan item pernyataan "saya selalu mengikuti tren yang sedang terjadi" memiliki nilai tertinggi. Artinya responden setuju jika mereka lebih tertarik dan mengikuti tren yang sedang ada. Dengan naiknya tren bersepeda atau gowes di seluruh dunia pada kondisi pandemi ini menjadikan antusias masyarakat khususnya warga Kabupaten Tulungagung meningkat. Banyak dari mereka berdatangan ke toko sepeda untuk membeli produk yang diinginkan salah satunya seperti sepeda merek United. Kemudian pada indikator gaya konsumsi dengan item pernyataan "membeli sepeda United merupakan hal yang menyenangkan" memiliki nilai paling tinggi. Hal ini dikarenakan responden merasa senang dengan aktivitas berbelanja 
Aji Rama Prasetiyo \& Anik Lestari Andjarwati. Analisis Gaya Hidup Hedonis, Harga, dan Kualitas Produk serta Pengaruhnya terhadap Keputusan Pembelian Sepeda di Era Pandemi Covid-19

atau berburu produk sepeda yang mereka inginkan seperti salah satunya sepeda dengan merek United. Mereka rela mengeluarkan nominal yang tidak sedikit untuk membeli sepeda dengan tipe tertentu yang menunjang kegiatan bersepeda. Terdapat beberapa responden yang setuju jika mereka hanya merasa senang dengan suasana belanja dan berburu sepeda meskipun sebenarnya sepeda tersebut jarang digunakan.

Lebih lanjut hasil tertinggi pada indikator tempat yakni item pernyataan "kafe merupakan tempat favorit saya berkumpul dengan teman komunitas sepeda". Hal ini membuktikan responden di Kabupaten Tulungagung lebih suka menghabiskan waktunya di kafe untuk beristirahat dan mengobrol dengan teman-teman komunitas ataupun keluarga setelah melakukan ativitas bersepeda. Kafe dirasa tempat yang paling nyaman untuk melepas kelelahan setelah beraktivitas. Dengan nuansa estetik dan berbagai pilihan menu yang kekinian sangat mendukung untuk dijadikan tempat bagi responden yang suka mengikuti perkembangan tren. Kafe juga dirasa dapat dijadikan tempat yang sesuai untuk mengabadikan momen kebersamaan dengan foto bersama teman maupun keluarga. Kemudian pada indikator rekreasi nilai tertinggi pada item pernyataan "saya lebih senang menghabiskan waktu dengan kegiatan bersepeda menggunakan sepeda United". Hal ini menunjukkan bahwa responden lebih tertarik dan merasa senang apabila mereka menghabiskan waktunya dengan berada di luar rumah untuk kegiatan bersepeda menggunakan sepeda United. Dengan berada di luar rumah mereka merasakan suasana baru yang menimbulkan nuansa kebahagiaan karena sebelumnya terdapat larangan untuk keluar rumah di masa Pandemi Covid-19. Tren gowes yang sedang naik daun menjadi sarana kegiatan yang bisa dilakukan responden yang merindukan aktivitas di luar rumah. Mayoritas responden dalam penelitian ini adalah laki-laki dengan rata-rata pendapatan lebih dari Rp3.000.000. Hal ini dikarenakan responden laki-laki lebih tertarik dengan kegiatan olahraga fisik salah satunya bersepeda. Mereka juga lebih mengerti tentang fitur dari sepeda yang akan dibeli untuk menunjang kegiatannya. Responden laki-laki tidak memperhitungkan harga barang yang akan dibeli. Mereka akan mengeluarkan berapapun uang untuk memuaskan hobi yang digemari.

\section{Pengaruh Harga terhadap Keputusan Pembelian}

Pada penelitian ini variabel harga secara positif dan signifikan memengaruhi keputusan pembelian sepeda United di Kabupaten Tulungagung. Hal tersebut menunjukkan bahwa ketika persepsi harga yang diterima oleh responden sesuai, maka dapat meningkatkan keputusan pembelian terhadap sepeda United. Hasil penelitian ini membuktikan konsep teori dari Assael (1998:235) hal terpenting yang membentuk persepi pelanggan untuk membantu menentukan keputusan pembelian terhadap strategi pemasaran adalah harga. Hasil penelitian ini mendukung Andrianto \& Idris (2013) harga berpengaruh terhadap keputusan pembelian secara signifikan. Lebih lanjut Lien et al. (2015), Hustić \& Gregurec (2015), Mulya Firdausy \& Idawati (2017) dan Kasanti et al. (2019) smenunjukkan variabel harga memengaruhi keputusan pembelian secara signifikan. Namun, terdapat perbedaan dengan Pardede \& Haryadi (2017) harga tidak berpengaruh terhadap keputusan pembelian. Hal tersebut disebabkan terdapat perbedaan obyek dan wilayah dari masing-masing penelitian.

Penetapan harga (price skimming) yang menyesuaikan dengan kualitas dan spesifikasi produk dirasa mampu memberikan respon positif untuk membuat seseorang memutuskan membeli sepeda merek United. PT. Terang Dunia Internusa harus memastikan terlebih dahulu bahwa kualitas yang ada pada produk sepeda tersebut sesuai dengan value yang akan diterima atau sama dengan biaya yang dikeluarkan oleh responden. Sebaliknya jika perusahaan ingin menetapkan harga rendah mereka boleh menurunkan kualitas yang ada pada sepeda United untuk menyesuaikan dengan biaya produksi agar tetap memperoleh keuntungan dari penjualan produk. Dengan memberikan harga jual yang sesuai dengan rata-rata pendapatan masyarakat dari suatu daerah membuat United akan kembali diminati. Dalam upayanya meningkatkan penjualan sepeda United PT. Terang Dunia Internusa meluncurkan berbagai produk baru yang menawarkan harga dari terendah, menengah, hingga termahalnya. Hal tersebut dilakukan dengan tujuan memenangkan persaingan disemua segmentasi.

Responden laki-laki dengan usia 16-30 tahun mendominasi dalam penelitian ini. Hal ini dikarenakan responden laki-laki lebih memiliki ketertarikan hobi dalam dunia olahraga. Dengan bersepeda mereka merasakan adrenalin baru yang membuat kesenangan tersendiri. Rata-rata penghasilan dari responden 
lebih dari Rp3.000.000 setiap bulannya. Dengan penghasilan sebesar itu mereka dapat memperoleh tipe sepeda United yang sesuai dengan kebutuhan dan dapat digunakan untuk aktivitas bersepeda.

\section{Pengaruh Kualitas Produk terhadap Keputusan Pembelian}

Dari analisis data, kualitas produk memiliki pengaruh terhadap keputusan pembelian sepeda United di Kabupaten Tulungagung secara positif dan signifikan. Hal ini menunjukkan ketika kualitas produk yang dimiliki oleh sepeda United berkualitas baik maka akan meningkatkan keputusan pembelian. Hasil tersebut membuktikan teori yang dikemukakan oleh Aaker (2008:127) bahwa kualitas produk mampu mengefektifkan semua elemen strategi pemasaran untuk menciptakan keputusan-keputusan pembelian. Hasil penelitian ini mendukung penelitian Alfred (2013) bahwa kualitas produk memengaruhi secara signifikan dan positif pada keputusan pembelian. Penelitian mendukung Ago et al. (2015) dan Rahman \& Sitio (2019) yang menunjukkan kualitas produk memiliki pengaruh yang signifikan terhadap keputusan pembelian. Tetapi, terdapat perbedaan hasil dengan Pardede \& Haryadi (2017) yang menyatakan kualitas produk tidak berpengaruh pada keputusan pembelian. Hal ini disebabkan adanya perbedaan obyek penelitian dan wilayah yang digunakan untuk memberikan kuisioner kepada responden.

Terdapat empat indikator yang dipakai dalam mengukur variabel kualitas produk, yaitu kinerja (performance), daya tahan (durability), fitur (feature), serta keragaman produk. Sudah menjadi keharusan dari setiap produk yang dijual harus dapat digunakan sebagaimana mestinya. Kinerja dari sepeda United sudah tidak diragukan lagi karena pasti dapat berfungsi dengan baik. Dengan berfungsinya semua komponen yang ada pada sepeda United membuat orang tidak akan ragu untuk menggunakannya. Daya tahan juga menjadi unsur penting untuk memberikan manfaat tambahan lainnya. Apabila sepeda United tidak memiliki daya tahan yang bagus maka umur pemakaian juga tidak dapat berlangsung lama. Sehingga dalam proses pembuatannya United memberikan bahanbahan yang berkualitas agar dapat digunakan dalam jangka waktu yang lama tanpa mengalami kendala sedikitpun. Saat ini inovasi baru untuk fitur sepeda sangatlah beragam. United sendiri mengeluarkan beberapa fitur baru untuk meningkatkan perhatian konsumen. Brand sepeda United menciptakan sepeda listrik dan sepeda kota dengan masing-masing fitur canggihnya. Fitur tersebut diharapkan mampu memberikan manfaat lebih bagi calon konsumen. Selain ketiga hal sebelumnya, United juga menambahkan berbagai pilhan tipe dan warna. Dengan pilihan yang beragam membuat konsumen dapat menentukan produk dengan kualifikasi yang sesuai dengan kebutuhan tanpa harus beralih ke merek sepeda lainnya.

Responden dengan tingkat pendidikan SMA/SMK mendominasi pada penelitian ini. Hal tersebut dikarenakan dengan pengetahuan yang dimiliki, mereka mampu menentukan pilihan yang sesuai baik dari segi kualitas bahan dan fitur untuk menunjang kebutuhan bersepeda. Mayoritas pendapatan yang diperoleh responden dalam penelitian ini sebesar lebih dari Rp3.000.000. Dengan penghasilan tersebut mereka dapat membeli sepeda United dengan kualitas yang sudah cukup untuk menunjang aktivitas bersepeda.

\section{KESIMPULAN}

Dari hasil penelitian dan pembahasan dapat disimpulkan bahwa terdapat pengaruh antara gaya hidup hedonis, harga, dan kualitas produk secara signifikan dan positif terhadap keputusan pembelian sepeda United di era pandemi Covid-19 (Studi pada pengguna sepeda United di Kabupaten Tulungagung). Keterbatasan yang ada dalam penelitian ini dikarenakan hanya menyebarkan kuisioner secara online di wilayah Kabupaten Tulungagung. Penelitian berikutnya dapat memperluas jangkauan wilayah dan melakukan pengumpulan data secara offline apabila memungkinkan untuk mendapatkan pernyataan terbuka dari responden sehingga didapatkan jawaban yang lebih mendalam terkait variabel independen. Penelitian berikutnya diharapkan dapat menggunakan variabel lain seperti promosi, citra merek, citra perusahaan, dan kelompok acuan. 
Aji Rama Prasetiyo \& Anik Lestari Andjarwati. Analisis Gaya Hidup Hedonis, Harga, dan Kualitas Produk serta Pengaruhnya terhadap Keputusan Pembelian Sepeda di Era Pandemi Covid-19

Implikasi praktis dari hasil penelitian ini PT. Terang Dunia Internusa sebagai produsen yang memproduksi sepeda dengan merek United diharapkan dapat memberikan inovasi-inovasi baru seperti sepeda dengan tenaga listrik, fitur pengukur kecepatan dan jarak tempuh untuk menghasilkan sepeda sesuai permintaan yang ada dipasar dengan kualitas yang bagus dan harga yang dapat dijangkau oleh seluruh kalangan masyarakat Indonesia. Hal tersebut perlu dilakukan agar merek United tetap mendapatkan perhatian dan menjaga eksistensi karena seiring dengan ketatnya persaingan bisnis yang terjadi. Selain itu produsen diharuskan untuk selalu mengamati perilaku konsumen terutama gaya hidup yang selalu mengalami perubahan akibat perkembangan zaman. Dengan begitu pihak perusahaan dapat menentukan strategi marketing yang tepat untuk menciptakan keputusan pembelian. Adapun implikasi teoritis yang terdapat pada penelitian ini menunjukkan variabel gaya hidup hedonis berpengaruh paling besar dibandingkan dengan harga dan kualitas produk, sehingga apabila gaya hidup hedonis masyarakat meningkat hal tersebut akan menaikkan keputusan pembelian.

\section{DAFTAR PUSTAKA}

Aaker, D. (2008). Manajemen Ekuitas Merek. Jakarta: Mitra Utama.

Ago, G., Suharno, Mintarti, S., \& Hariyadi, S. (2015). Effect of Product Quality Perception , Trust , and Brand Image on Generic Drug Buying Decision And Consumer Satisfaction of Hospital Patientsi In East Kalimantan. European Journal of Business and Management, 7(14), 50-69.

Alfred, O. (2013). Influences of Price and Quality on Consumer Purchase of Mobile Phone In The Kumasi Metropolis In Ghana A Comparative Study. European Journal of Business and Management, 5(1), 179-199.

Ananingsih, T., Hasiholan, L. B., \& Wahyono, E. H. (2018). Pengaruh Kualitas Produk, Promosi, Harga dan Saluran Distribusi terhadap Keputusan Pembelian Produk Johnson and Johnson Indonesia. Pandanaran Journal of Management, 2(1), 1-10.

Andrianto, H. N., \& Idris. (2013). Pengaruh Kualitas Produk, Citra Merek, Harga, dan Promosi terhadap Keputusan Pembelian Mobil Jenis MPV Merek Toyota Kijang Inova Di Semarang. Diponegoro Journal Of Management, 2(3), 1-10.

Assael, H. (1998). Customer Behavior and Marketing Action. New York: International Thomson Publishing.

Babin, B. J., Darden, W. R., \& Griffin, M. (1994). Utilitarian Shopping Value. Journal of Consumer Research, 20(4), 644-657.

Brata, B. H., Husani, S., \& Ali, H. (2017). The Influence of Quality Products, Price, Promotion, and Location to Product Purchase Decision on Nitchi at PT. Jaya Swarasa Agung in Central Jakarta. Saudi Journal of Business and Management Studies, 2(4B), 433-445. https://doi.org//10.21276/sjbms

Chaney, D. (2004). Lifestyle Sebuah Pengantar Komprehensif. Yogyakarta: Jalasutra.

Engel, J. F., Blackwell, R. D., \& Miniad, P. (1995). Perilaku Konsumen. Jakarta: Bina Rupa Aksara.

Handayani, M. (2020). COVID-19 Yang Membuat 60 Persen Industri Terpukul. (https://voi.id/berita/5276/covid-19-yang-membuat-60-persen-industri-terpukul, diakses pada 15 Oktober 2020)

Hustić, I., \& Gregurec, I. (2015). The Influence of Price on Customer's Purchase Decision. Central European Conference on Information and Intelligent Systems, 1-6. http://www.ceciis.foi.hr/app/public/conferences/1/ceciis2015/papers/754.pdf 
Indrawati, D. (2015). Pengaruh Citra Merek dan Gaya Hidup Hedonis terhadap Keputusan Pembelian Jilbab "Zoya". Jurnal Riset Ekonomi Dan Manajemen, 15(2), 302. https://doi.org/10.17970/jrem.15.150207.id

Kasali, R. (2003). Membidik Pasar Indonesia: Segmentasi, Targeting, dan Positioning. Jakarta: Gramedia Pustaka Utama.

Kasanti, N., Wijaya, A., Ekonomi, F., \& Indonesia, U. P. (2019). Pengaruh Harga dan Kualitas Produk terhadap Keputusan Pembelian Produk Safety Merek Proguard pada PT AIM Safety Indonesia. Asian Journal of Innovation and Entrepreneurship, 4(1), 43-51.

Kotler, P., \& Armstrong, G. (2012). Prinsiop-prinsip Pemasaran. Edisi 13. Jakarta: Erlangga.

Kotler, P., \& Keller, K. L. (2012). Manajemen Pemasaran. Edisi 13. Jakarta: Erlangga.

Kristian, Y. Y. (2020). Bersepeda di Tengah Pandemi. (https://www.uc.ac.id/library/bersepeda-ditengah-pandemi/, diakses pada 20 Januari 2021)

Lien, C. H., Wen, M. J., Huang, L. C., \& Wu, K. L. (2015). Online Hotel Booking: The Effects of Brand Image, Price, Trust and Value on Purchase Intentions. Asia Pacific Management Review, 20(4), 210-218. https://doi.org/10.1016/j.apmrv.2015.03.005

Malhotra, N. K. (2017). Riset Pemasaran Pendekatan Terapan. Jakarta: PT. Gramedia Pustaka Utama.

Mulya Firdausy, C., \& Idawati, R. (2017). Effects of Service Quality, Price and Promotion on Customers' Purchase Decision of Traveloka Online Airline Tickets in Jakarta, Indonesia. International Journal of Management Science and Business Administration, 3(2), 42-49. https://doi.org/10.18775/ijmsba.1849-5664-5419.2014.32.1004

Nurhanisah, Y. (2019). Indonesia Raih Posisi Kelima di Industri Manufaktur Dunia. (https://www.indonesiabaik.id/infografis/indonesia-raih-posisi-kelima-di-industri-manufakturdunia, diakses pada 21 September 2020)

Pandensolang, J. D., \& Tawas, H. N. (2015). Pengaruh Diferensiasi, Kualitas Produk dan Ekuitas Merek terhadap Keputusan Pembelian coca-cola pada PT. Bangun Wenang Beverges Company di Manado. Jurnal Emba, 3(3), 1113-1124. https://doi.org/10.35794/emba.v3i3.10117

Pardede, R., \& Haryadi, T. Y. (2017). Pengaruh Persepsi Harga dan Kualitas Produk terhadap Keputusan Pembelian Konsumen Yang Dimediasi Kepuasan Konsumen. Journal of Business \& Applied Management, 10(1). https://doi.org/10.30813/jbam.v10i1.870

Rahman, H. A., \& Sitio, A. (2019). The Effect of Promotion and Product Quality Through Purchase Decision on the Customer Satisfaction of Bohemian Project.Id Products. International Journal of Engineering Technologies and Management Research, 6(1), 55-72. https://doi.org/10.29121/ijetmr.v6.i1.2019.346

Rinandiyana, L. R., Kusnandar, D. L., \& Bahren, B. (2018). Literasi Ict dan Perilaku Hedonist Dalam Memilih Tempat Wisata di Kalangan Kelas Menengah Sebagai Pengaruh Gaya Hidup. Unsoed Journal and Proceeding, 8(1), 1-13. http://jp.feb.unsoed.ac.id/index.php/sca1/article/view/1202

Rizaldi, M. (2016). Pengaruh Gaya Hidup Hedonis Terhadap Keputusan Pembelian Pada Smartphone Di Kalangan Mahasiswa Studi Pada Mahasiswa Fakultas Ekonomi Universitas Negeri 
Aji Rama Prasetiyo \& Anik Lestari Andjarwati. Analisis Gaya Hidup Hedonis, Harga, dan Kualitas Produk serta Pengaruhnya terhadap Keputusan Pembelian Sepeda di Era Pandemi Covid-19

$\begin{array}{llll}\text { Surabaya. Jurnal } & \text { Ilmu }\end{array}$ https://jurnalmahasiswa.unesa.ac.id/index.php/jim/article/view/17525

Schiffman, L., \& Kanuk, L. L. (2010). Consumer Behaviour (10th ed). New Jersey: Pearson Prentice Hall.

Setiadi, N. J. (2010). Perilaku Konsumen. Cetakan 4. Edisi Revisi. Jakarta: Kencana.

Sumarwan, U. (2014). Perilaku Konsumen Teori dan Penerapannya dalam Pemasaran. Bogor: Ghalia Indonesia.

Susianto, H. (1993). Studi Gaya Hidup sebagai Upaya Mengenali Kebutuhan Anak Muda. Jakarta: Gramedia Pustaka Utama.

Tjiptono, F. (2008). Strategi Pemasaran. Edisi 3. Yogyakarta: Andi Offset.

Top Brand Award.(2020). Top Brand Index. (https://www.topbrand-award.com/top-brand-index/, diakses pada 25 Oktober 2020)

Unitedbike.com. (2020). About Us. (https://www.unitedbike.com/about, diakses pada 15 Oktober 2020)

Utami, C. W. (2012). Manajemen Ritel Strategi Dan Implementasi Ritel Modern. Jakarta: Salemba Empat.

Yamin, E. M. (2017). Mengenal Kota Tulungagung. (https://backpackerjakarta.com/mengenal-kotatulungagung/, diakes pada 25 Januari 2021)

Yohanes, D. (2020). Komunitas Pesepeda Berkembang di Tulungagung, Angka Penjualan Sepeda di PDS Meningkat. (https://jatim.tribunnews.com/2020/06/15/komunitas-pesepeda-berkembangdi-tulungagung-angka-penjualan-sepeda-di-pds-meningkat?page=all, diakses pada 25 Januari 2021) 